\title{
Are Vitamin D Drops Containing 400 IU Daily Adequate for Preventing Vitamin D Deficiency?
}

\author{
Hüseyin Anıl Korkmaz \\ Balıkesir Atatürk State Hospital, Clinic of Pediatric Endocrinology, Balıkesir, Turkey
}

\begin{abstract}
Dear Editor,
The adequacy of vitamin $D$ intake is necessary to optimize the bone health during the rapid growing phase of infancy. Vitamin $\mathrm{D}$ also affects many organs playing an important role in maintaining general health. Vitamin $D$ deficiency may be associated with cardiovascular disease, diabetes, cancer, and autoimmune diseases (1).

The incidence of vitamin D insufficiency and nutritional rickets has decreased in Turkey following the nationwide vitamin $\mathrm{D}$ prophylaxis programme undertaken by the Turkish Ministry of Health in 2005. This programme provides free vitamin D drops containing $400 \mathrm{IU}$ daily for all children under 12 months of age (2). Our study demonstrated that this dose is not adequate for preventing vitamin $D$ deficiency and insufficiency (3). Although Izmir has an abundance of sunshine almost throughout the year, our study showed that $40.9 \%$ of infants were sufficient, $28.4 \%$ of infants were insufficient, and $30.7 \%$ of infants were deficient in vitamin D levels on $400 \mathrm{IU}$ of vitamin D supplementation (2). Halicioglu et al (4) also found that the rates of vitamin $\mathrm{D}$ deficiency and insufficiency were high in infants from a temperate region of Turkey who received daily $400 \mathrm{IU}$ vitamin D supplementation. Because we found a high prevalence of vitamin D insufficiency and deficiency in infants who received $400 \mathrm{IU}$ of vitamin D supplementation, we speculated that vitamin $D$ prophylaxis dose should be increased from $400 \mathrm{IU}$ to 600 or $800 \mathrm{IU}$ in infants aged 0-12 months. We observed no patients with signs of hypocalcaemia, fits or tetany, and rickets in our study because dietary calcium intake was adequate in our patients despite vitamin $\mathrm{D}$ deficiency or insufficiency. We also reported high rates of maternal vitamin $D$ deficiency and insufficiency in our study (2). The infants are at a high risk of vitamin D deficiency in the first year of life.
\end{abstract}

Vitamin $\mathrm{D}$ supplementation is also important for decreasing the prevalence of severe early childhood caries with maintaining normal serum 25-hydroxy vitamin $D$ (5).

Vitamin D prophylaxis dose might spark a debate in infants for maintaining general health. Further investigations would therefore be needed to clarify the optimal amount of vitamin $D$ supplementation to the infants aged 0-12 months.

Keywords: Vitamin D insufficiency, vitamin D deficiency, vitamin D supplementation

Received: 29.02.2016

Accepted: 08.03.2016

Peer-review: Internal peer-reviewed.

Conflict of Interest: None declared

Financial Disclosure: The author declared that this study has received no financial support.

\section{References}

1. El-Fakhri N, McDevitt H, Shaikh MG, Halsey C, Ahmed SF Vitamin D and its effects on glucose homeostasis, cardiovascular function and immune function. Horm Res Paediatr 2014;81:363-378. Epub 2014 Apr 26

2. Hatun $S$, Özkan B, Bereket A. Vitamin D deficiency and prevention: Turkish experience. Acta Pediatr 2011;100:11951199. Epub 2011 Jul 4

3. Gülez P, Korkmaz HA, Özkök D, Can D, Özkan B. Factors Influencing Serum Vitamin D Concentration in Turkish Children Residing in Izmir: A Single-Center Experience. J Clin Res Pediatr Endocrinol 2015;7:294-300.

4. Halicioglu O, Sutcuoglu S, Koc F, Yildiz O, Akman SA, Aksit S. Vitamin D status of exclusively breastfed 4-month-old infants supplemented during different seasons. Pediatrics 2012;130:921-927. Epub 2012 Sep 24

5. Schroth RJ, Levi JA, Sellers EA, Friel J, Kliewer E, Moffatt ME. Vitamin D status of children with severe early childhood caries: a case-control study. BMC Pediatr 2013;13:174.

\footnotetext{
Address for Correspondence

Hüseyin Anıl Korkmaz MD, Balıkesir Atatürk State Hospital, Clinic of Pediatric Endocrinology, Balıkesir, Turkey

Phone: +90266 2213510 E-mail: drkorkmazanil@hotmail.com

C) Journal of Clinical Research in Pediatric Endocrinology, Published by Galenos Publishing.
} 